et al., we observed no such age-dependent decrease in GFR (Fig. 1). Our results show a decrease in GFR (as estimated with the use of the Modification of Diet in Renal Disease [MDRD] formula) after donation in all three age groups but with stable kidney function over the years. Our findings support the conclusions of Ibrahim et al. and also indicate that kidney donation by older donors may be considered relatively safe over time, since kidney function does not appear to decline progressively.

Leonienke F.C. Dols, M.D.

Willem Weimar, M.D., Ph.D.

Jan N.M. IJzermans, M.D., Ph.D.

Erasmus Medical Center

3015 CE Rotterdam, the Netherlands

j.ijzermans@erasmusmc.nl

THE AUTHORS REPLY: Davis and Cooper note that the Minnesota donor cohort is almost entirely white, whereas in the United States as a whole, $86 \%$ of donors are white. ${ }^{1}$ They also comment on the ideal control group for kidney donors. As we note in our discussion, the ideal group would have been persons who were deemed suitable for donation but who did not donate. We compared the rate of incident ESRD among our donors with the rate among whites in the United States; most of our donors ( $>60 \%$ ) are residents of Minnesota. In 2006, the rate of incident ESRD in Minnesota was almost identical to that in the rest of the country (359.8 and 363.2 cases per million, respectively). In previous years, the rate was 20 to 40 cases per million lower in Minnesota than in the rest of the country. ${ }^{2}$ We hope that the Renal and Lung Donors Evaluation (RELIVE) study (ClinicalTrials. gov number, NCT00608283), which will report on more than 8000 kidney donors, with better minority representation and more comparable controls, will address some of these concerns.
Freeman points out the critical finding that some donors had hypertension that was poorly controlled or undiagnosed. We strongly agree that there is a need to aggressively monitor and treat blood-pressure elevations in all kidney donors.

Ross and Thistlethwaite note that 3 of the 11 donors in whom ESRD developed were nonwhite. One was a black woman, one an Asian woman, and one a Native American man. The Asian donor had hypertension-related ESRD; the cause was unknown in the case of the other two. There were 93 black donors, 39 Asian donors, and 76 NativeAmerican donors, yielding an incidence of ESRD of $1.1 \%, 2.6 \%$, and $1.3 \%$, respectively. Although the numbers are too small to draw conclusions, these data clearly indicate that race or ethnic background should be considered in the overall assessment of risk, an area that our study could not fully address.

Dols et al. note that there was no age-related decline in GFR in their longitudinal studies of GFR in donors. We have measured GFR longitudinally in 38 of our donors and noted a decline of $0.59 \pm 3.84 \mathrm{ml}$ per minute per year, a rate that is similar to that observed in our cross-sectional measurement of GFR. At the second GFR measurement, GFR had decreased in 24 donors, had stayed the same in 2, and had actually risen in 12 , suggesting that a GFR decline with aging may not be universal.

Hassan N. Ibrahim, M.D.

Arthur J. Matas, M.D.

University of Minnesota

Minneapolis, MN 55414

ibrah007@umn.edu

1. Gibney EM, King AL, Maluf DG, Garg AX, Parikh CR. Living kidney donors requiring transplantation: focus on African Americans. Transplantation 2007;84:647-9.

2. Renal Data System. USRDS 2008 annual data report: atlas of chronic kidney disease and end-stage renal disease in the United States. Bethesda, MD: National Institute of Diabetes and Digestive and Kidney Diseases, 2008.

\title{
A Surgical Safety Checklist
}

TO THE EDITOR: Haynes et al. (Jan. 29 issue) ${ }^{1}$ report on a surgical safety checklist to reduce morbidity and mortality in a global population. Transferring the concept of checklists from aviation to surgery sounds intuitively sensible. However, to claim that the use of checklists can reduce the perioperative rate of death by more than $30 \%$, based on extrapolation across a mixture of hospitals in developed and developing countries, may be misleading and counterproductive. In any case, all except one of the participating hospitals in developed countries had a preintervention rate of death that exceeded the published normal range of $0.4 \%$ to $0.8 \%$. Indeed, the rate of death in the 
only hospital at the extreme end of the normal range increased from $0.8 \%$ to $1.4 \%$ after the intervention.

In the United Kingdom, the National Patient Safety Agency has responded rapidly to this study by issuing a safety alert to all National Health Service hospitals; this alert requires the hospitals to use a modified 26-point checklist by $2010 .^{2}$ Although we support this initiative because it is likely to promote greater team cooperation, we are concerned that the implied reduction in the perioperative rate of death is unlikely to be realized in the United Kingdom, and ultimately, this may adversely affect credibility and compliance with this potentially valuable adjunct to safety measures for surgical patients.

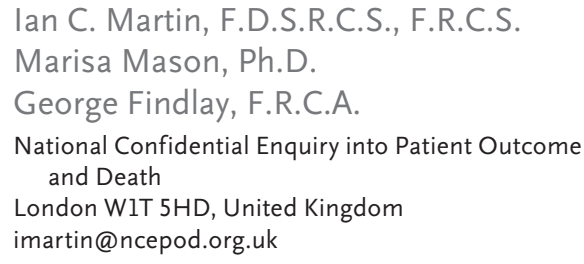

1. Haynes AB, Weiser TG, Berry WR, et al. A surgical safety checklist to reduce morbidity and mortality in a global population. N Engl J Med 2009;360:491-9.

2. National Patient Safety Agency. WHO surgical safety checklist. January 2009. (Accessed May 7, 2009, at http://www.npsa. nhs.uk/nrls/alerts-and-directives/alerts/safer-surgery-alert/.)

TO THE EDITOR: Haynes and colleagues show the benefit of the surgical safety checklist for improving perioperative care. Although the authors state that the intervention was neither "costly nor lengthy," information to support this statement was not presented. The length of the checklist must be considered, especially for the anesthetized patient who is prone to physiological disturbance, including hypothermia. Thus, it is unclear why a "time out" should be conducted after the induction of anesthesia, rather than immediately before the induction of anesthesia (this is particularly important in lower-income environments with less availability of physiological support). The significant benefits of education, checklist awareness, and increased resource utilization must be realized. The adoption of increased use of antibiotics and pulse oximetry may have accounted for the survival advantage in lower-income sites. It is possible that implementation of other monitoring devices, such as temperature monitoring, would further improve perioperative care. However, although all sites in the current study had access to pulse oximetry and prophylactic antibiotics, the additional costs associated with these resources were not disclosed. Many lower-income sites may lack funding for these resources.

Robert D. Sanders, M.B., B.S.

Imperial College London

London SW10 9NH, United Kingdom

robert.sanders@ic.ac.uk

Simon S. Jameson, M.B., B.S.

Stirling Royal Infirmary

Stirling FK8 2AU, United Kingdom

TO THE EDITOR: As reported by Haynes et al., the World Health Organization (WHO) Safe Surgery Saves Lives study shows strikingly large and important effects of checklists on the rates of inpatient complications, including death. The use of checklists will be promoted globally. ${ }^{1}$ Unfortunately, in addition to the weak preinterventionpostintervention design, the inference of effectiveness is not convincing for other reasons. The Hawthorne effect is discussed as a possible mechanism of effect, rather than as a study limitation. Apart from consideration of the possible effects of direct observation in the operating room, other artifacts of the research process are not considered. Clinical teams were fully aware that they were participants in a study of their own behavior. Surgical practice may well have been altered by this research context rather than by the checklist. Blinding is recommended to reduce such performance biases..$^{2,3}$ Clinicians could have been kept unaware of the study, and the checklist could have been introduced as a matter of hospital policy in precisely the ways intended for subsequent routine use. The opportunity to reliably estimate the size of the effects of checklist introduction in a trial has been missed. Dedicated, sophisticated study of the Hawthorne effect is long overdue. ${ }^{4}$

Jim McCambridge, Ph.D.

London School of Hygiene and Tropical Medicine

London WCIE 7HT, United Kingdom

jim.mccambridge@Ishtm.ac.uk

Kypros Kypri, Ph.D.

University of Newcastle

Newcastle, NSW 2300, Australia

Diana R. Elbourne, Ph.D.

London School of Hygiene and Tropical Medicine London WClE 7HT, United Kingdom

1. News BBC. Surgical checklist saves lives. January 14, 2009. (Accessed May 7, 2009, at http://news.bbc.co.uk/1/hi/health/ 7825780.stm.)

2. Boutron I, Guittet L, Estellat C, Moher D, Hróbjartsson A, 
Ravaud P. Reporting methods of blinding in randomized trials assessing nonpharmacological treatments. PLoS Med 2007; 4(2):e61.

3. Higgins JPT, Altman DG, eds. Assessing risk of bias in included studies. In: Higgins JPT, Green S, eds. Cochrane handbook for systematic reviews of interventions, version 5.0.0. (updated February 2008). Oxford, England: Cochrane Collaboration, 2008. (Accessed May 7, 2009, at http://www.cochrane-handbook. org/.)

4. McCambridge J, Day M. Randomized controlled trial of the effects of completing the Alcohol Use Disorders Identification Test questionnaire on self-reported hazardous drinking. Addiction 2008;103:241-8.

TO THE EDITOR: Haynes et al. discuss the beneficial effects of using checklists for surgical procedures. Many years ago, before attending medical school, I was a fighter pilot flying F-86 Sabrejets in the Air Force. I and most of my flying colleagues always used checklists that were strapped to our thighs while we were sitting in the cockpit. Every one of the myriad switches, gauges, dials, handles, and circuit breakers had to be properly set or checked. Procedures had to be followed assiduously, especially during an emergency. Checklists helped us do that. Each of us knew that a careless mistake could lead to our death. By contrast, if physicians or nurses make a careless mistake, someone else suffers or dies. Many of us evince too cavalier an attitude in working with patients. If all of us in medicine thought our own lives were at risk, you can bet a lot fewer mistakes would be made. Requiring the use of checklists is an excellent way to reduce errors and keep our patients safer.

David C. Levin, M.D.

Thomas Jefferson University Hospital Philadelphia, PA 19107

david.levin@jeffersonhospital.org

THE AUTHORS REPLY: Martin et al. express concern that the rates of death in our study were not "normal" and that the beneficial results observed may therefore not be generalizable. We well recognize that an eight-hospital study cannot provide a precise estimate of the magnitude of reduction in harm that is possible from broad implementation of the checklist. However, the larger criticism is flawed. The rates of death that we reported were for procedures conducted in the study operating rooms, not for hospital-wide procedures; the case mix varied widely among hospitals, and the hospitals themselves had enormous diversity. In ad- dition, the normal rate of postoperative death is unknown for the mix of cases observed in this international group of hospitals; a comparison with data from limited studies in developed countries would be invalid.

Sanders and Jameson correctly point out that the cost and time involved in such an intervention are important considerations. The checklist was designed to be brief; in testing, we aimed for a total duration of less than 2 minutes in routine situations, as shown in a training video provided to the study sites. ${ }^{1}$ The "time out" occurs after induction of anesthesia because it is not always practical to have the surgeon present before induction. In addition, errors may be introduced in the period between the induction of anesthesia and skin incision, including incorrect draping and delay of antibiotic administration. The cost of providing pulse oximetry and prophylactic antibiotics is an important concern. However, the WHO recommends that these resources be used as minimum standards for safe surgery and that the value of elective surgery in their absence be critically examined. ${ }^{2}$ In clinical settings without oximetry, as many as 1 in 150 patients has been reported to have died from anesthesia-related causes, ${ }^{3}$ and a surgical infection rate of more than $20 \%$ has been reported in settings without appropriate prophylactic antibiotics. ${ }^{4}$

McCambridge et al. are legitimately concerned about the role observation may have played in the results. The precise cause-and-effect relationship between the checklist program and the observed reduction in complications is unclear. Observation could have produced a Hawthorne effect by three possible mechanisms. First, the presence of an observer may have affected outcomes, but, as noted, we found no such effect. Second, teams may have used the checklist more assiduously because of the ongoing study, but this would not weaken any checklist effect. Finally, there is the possibility that the performance of the operative teams improved because of their awareness of being studied. However, we would recommend that any attempt to implement the checklist include monitoring of basic surgical outcomes, resulting in a similar scrutiny of results.

Levin astutely points out that lessons from aviation can be applied to improve safety in health care. The design of the WHO checklist was in- 
formed by experience from aviation and other industries. The use of checklists enhances both patient safety and clinical professionalism.

Alex B. Haynes, M.D., M.P.H.

Atul A. Gawande, M.D., M.P.H.

Harvard School of Public Health

Boston, MA 02115

safesurgery@hsph.harvard.edu
1. Safesurg.org home page. (Accessed May 7, 2009, at http:// www.safesurg.org.)

2. World Alliance for Patient Safety. WHO guidelines for safe surgery. Geneva: World Health Organization, 2008.

3. Ouro-Bang'na Maman AF, Tomta K, Ahouangbévi S, Chobli M. Deaths associated with anaesthesia in Togo, West Africa. Trop Doct 2005;35:220-2.

4. Fehr J, Hatz C, Soka I, et al. Antimicrobial prophylaxis to prevent surgical site infections in a rural sub-Saharan hospital. Clin Microbiol Infect 2006;12:1224-7.

\section{Asthma Induced by a Thermal Printer}

TO THE EDITOR: Point-of-sale terminals are devices used worldwide for credit-card or debit-card transactions or to print a variety of coupons. These machines print receipts on thermal paper covered with N-propyl-acrylamide and acrylate tints.

We report on a nonsmoking 62-year-old woman without atopy in whom asthma symptoms developed after she had worked for 20 years selling lottery tickets inside a 4- $\mathrm{m}^{3}$ kiosk. For the past 3 years, she had been using a point-of-sale terminal to print lottery tickets. She had a 2.5-year history of rhinoconjunctivitis, facial edema, cough, shortness of breath, and wheezing. These symptoms occurred within 30 to 60 minutes after she arrived at her workplace and diminished during days away from the workplace. She controlled the symptoms by using inhaled bronchodilators and pulses of oral corticosteroids. She required emergency treatment on three occasions: 8,6 , and 4 months before we examined her.

On evaluation at our clinic, there were no signs of atopy; baseline spirometric measurements were normal, as was the fraction of exhaled nitric oxide $\left(\mathrm{FE}_{\mathrm{NO}}\right)$, at $14 \mathrm{ppb}$. The provocative concentration of inhaled methacholine required to reduce the forced expiratory volume in 1 second $\left(\mathrm{FEV}_{1}\right)$ by $20 \%\left(\mathrm{PC}_{20}\right)$ was $6.18 \mathrm{mg}$ per milliliter (normal value, $>16.0 \mathrm{mg}$ per milliliter). Patch tests that included several acrylates (Martí Tor) were negative. We performed a bronchial challenge in a $7-\mathrm{m}^{3}$ chamber, as previously described. ${ }^{1}$ The patient painted on a cardboard for 30 seconds with the tint provided by the lottery company, which contained trimethylolpro-

\begin{tabular}{|c|c|c|c|c|c|}
\hline \multirow[t]{3}{*}{ Variable } & Baseline & $\begin{array}{l}\text { Placebo } \\
\text { Challenge }\end{array}$ & \multicolumn{3}{|c|}{ Bronchial Challenge } \\
\hline & & & $\begin{array}{l}\text { Trimethylolpropane } \\
\text { Triacrylate, } 30 \mathrm{sec}\end{array}$ & $\begin{array}{l}\text { Trimethylolpropane } \\
\text { Triacrylate, } 90 \mathrm{sec}\end{array}$ & $\begin{array}{l}\text { Printing Coupons, } \\
90 \mathrm{sec}\end{array}$ \\
\hline & day 0 & day 1 & \multicolumn{2}{|c|}{ day 2} & day 10 \\
\hline $\mathrm{FEV}_{1}$ & $\begin{array}{l}1.96 \text { liters }(95 \% \\
\text { of predicted } \\
\text { value) }\end{array}$ & $\begin{array}{l}\text { No change for } \\
24 \mathrm{hr}\end{array}$ & $\begin{array}{l}19 \% \text { decrease at } \\
30 \mathrm{sec}\end{array}$ & $\begin{array}{l}45 \% \text { decrease at } 1 \\
\text { min; no late asth- } \\
\text { matic reaction }\end{array}$ & $\begin{array}{l}15 \% \text { decrease at } 1 \\
\text { min; no late asth- } \\
\text { matic reaction }\end{array}$ \\
\hline $\begin{array}{l}\text { Methacholine } \mathrm{PC}_{20}- \\
\mathrm{mg} / \mathrm{ml}\end{array}$ & 6.2 & ND & & $\begin{array}{l}1.68 \text { at } 24 \mathrm{hr} \text { after } \\
\text { challenge }\end{array}$ & $\begin{array}{l}3.91 \text { at } 24 \mathrm{hr} \text { after } \\
\text { challenge }\end{array}$ \\
\hline $\begin{array}{l}\text { Eosinophil count in sputum } \\
\text { — cells } / \mathrm{ml} \text { (\% of total } \\
\text { cells) } \dagger\end{array}$ & $262,056(7.2)$ & ND & & $\begin{array}{r}775,422(18.7) \text { at } 24 \\
\text { hr after challenge }\end{array}$ & ND \\
\hline $\mathrm{FE}_{\mathrm{NO}_{\mathrm{O}}}-\mathrm{ppb}$ & 14 & 12 & & $\begin{array}{l}22 \text { at } 24 \mathrm{hr} \text { after chal- } \\
\text { lenge }\end{array}$ & $\begin{array}{l}8 \text { at } 24 \mathrm{hr} \text { after chal- } \\
\text { lenge }\end{array}$ \\
\hline
\end{tabular}

$* \mathrm{FE}_{\mathrm{NO}}$ denotes the fraction of nitric oxide in exhaled air, $\mathrm{FEV}_{1}$ forced expiratory volume in 1 second, ND not done, and $\mathrm{PC}$ 20 $\mathrm{Provocative}$ concentration of inhaled methacholine.

$\uparrow$ Sputum eosinophils were measured by means of flow cytometry. Data are from Sastre et al. ${ }^{2}$ 